\title{
Pengaruh motivasi belajar, self esteem dan social support terhadap prestasi akademik mahasiswa S1 Pendidikan Akuntansi Universitas Negeri Malang angkatan 2015
}

\author{
Akhya Rizki Muhammad, Sulastri* \\ Universitas Negeri Malang, Jl. Semarang No. 5 Malang, Jawa Timur, Indonesia \\ *Penulis korespondensi, Surel: sulastri.fe@um.ac.id
}

Paper received: 2-2-2021; revised: 20-2-2021; accepted: 27-2-2021

\begin{abstract}
Abstrak
Prestasi akademik merupakan indikator untuk mengukur keberhasilan proses belajar mengajar seorang mahasiswa. Sebagian besar mahasiswa di perguruan tinggi memiliki tujuan utama untuk mencapai prestasi akademik yang bagus. Faktor yang mempengaruhi tercapainya prestasi akademik yang bagus bisa berasal dari dalam diri mahasiswa dan faktor dari luar mahasiswa, untuk itu penelitian ini mencoba untuk memeriksa pengaruh faktor motivasi belajar, self-esteem, dan social support terhadap prestasi akademik mahasiswa. Penelitian ini bertujuan untuk mengetahui: (1) Pengaruh motivasi belajar terhadap prestasi akademik; (2) Pengaruh self-esteem terhadap prestasi akademik; (3) Pengaruh social support terhadap prestasi akademik. Pendekatan penelitian yang digunakan yaitu kuantitatif dengan jenis penelitian kuantitatif eksplanasi. Teknik pengumpulan data yang digunakan adalah kuesioner. Subjek penelitian ini adalah mahasiswa S1 Pendidikan Akuntansi Universitas Negeri Malang angkatan 2015. Metode purposive sampling ditetapkan untuk memilih 109 responden. Teknik analisis data yang digunakan adalah uji regresi linier berganda. Hasil penelitian menunjukkan bahwa: (1) Terdapat pengaruh positif motivasi belajar terhadap prestasi akademik; (2) Terdapat pengaruh positif self-esteem terhadap prestasi akademik; (3) Terdapat pengaruh positif social support terhadap prestasi akademik. Sebesar 52\% prestasi akademik dipengaruhi oleh motivasi belajar, self-esteem, dan social support dan $48 \%$ dipengaruhi oleh faktor lain. Hal ini menunjukkan bahwa semakin tinggi motivasi belajar yang dimiliki, serta semakin tinggi self-esteem yang dimiliki, dan semakin tinggi social support yang diterima mahasiswa maka semakin tinggi tingkat prestasi akademik yang didapatkan. Saran yang berkaitan dengan penelitian ini bagi peneliti selanjutnya yaitu diharapkan pengumpulan data menggunakan wawancara agar mendapat informasi mendalam, dapat mengkaji faktor-faktor lain yang bisa meningkatkan prestasi akademik yang mungkin pengaruhnya lebih besar dari pada faktor yang diangkat dalam penelitian ini.
\end{abstract}

Kata kunci: prestasi akademik; motivasi belajar; self esteem; social support

\section{Pendahuluan}

Prestasi akademik merupakan kriteria keberhasilan proses akademis mahasiswa. Kebutuhan akan prestasi menjadi motivasi yang diperlukan untuk menjadi cara untuk meningkatan kualitas akademik mahasiswa yang digambarkan dari hasil prestasi akademik yang baik. Self esteem atau harga diri dan motivasi belajar termasuk dalam kategori faktor internal, social support atau dukungan sosial dari orang tua, dan faktor motivasi belajar yang merupakan faktor eksternal yang mempengaruhi peningkatan prestasi akademik mahasiswa.

Hamalik (2011) menyatakan motivasi belajar sangat menentukan tingkat keberhasilan belajar mahasiswa. Belajar tanpa adanya motivasi akan jauh dari hasil prestasi yang baik, sebab mahasiswa yang kurang motivasi tentu tidak akan melakukan aktivitas belajar. Hal ini merupakan tanda bahwa hal yang dilakukannya tidak merupakan kebutuhanya. Segala sesuatu yang menarik minat belum tentu menarik minat orang lain selama hal itu tidak merupakan kebutuhannya (Djamarah, 2011). Dengan adanya motivasi belajar untuk berprestasi, 
mahasiswa yang memiliki motivasi belajar untuk berprestasi yang tinggi akan memiliki kesiapan dan akan tahan untuk menghadapi kegagalan ataupun masalah-masalah, mereka juga akan memiliki keinginan untuk berkompetisi dengan orang lain yang memiliki motivasi belajar yang tinggi pula.

self esteem merupakan keyakinan dan kemampuan diri untuk bertindak dan menghadapi tantangan, Keyakinan dalam hak untuk bahagia, perasaan berharga, dan layak. Bustanova (2008) menambahkan self esteem merupakan penilaian seseorang secara umum terhadap dirinya sendiri, baik penilaian positif ataupun negatif yang pada akhirnya menghasilkan perasaan bahwa dirinya berharga dan berguna. Cara memandang dan merasakan diri sendiri yang akhirnya akan mempengaruhi seseorang dalam berhubungan sosial baik secara intrapersonal ataupun interpersonal. Cara pandang dan merasakan diri ini terbentuk dari pengalaman dalam keluarga, sekolah, hubungan pertemanan dan lingkungan sosial.

Self esteem merupakan salah satu aspek kepribadian yang merupakan kunci dalam pembentukan perilaku seseorang, karena akan sangat berpengaruh pada proses berpikir, tingkat emosi, keputusan yang diambil dalam proses perkuliahan yang memungkinkan seseorang menikmati dan lebih bersemangat dalam perkuliahan. Tingkat self esteem yang rendah pada diri mahasiswa kemungkinan akan mengganggu proses pembelajaran mahasiswa tersebut. Perilaku manusia secara umum ingin mempertahankan dan meningkatkan self esteem karena sebagai kebutuhan dasar (Greenberg, 2008).

Dukungan sosial merupakan sumber eksternal yang dapat memberikan bantuan bagi individu dalam mengatasi atau menghadapi suatu persoalan. Menurut King (2012) social support adalah umpan balik dari orang lain yang menunjukkan bahwa seseorang dicintai dan diperhatikan, dihargai, dan dihormati, dan dilibatkan dalam suatu kelompok. Sarafino (2006) mengemukakan teori buffering hypotesis merupakan teori yang menyatakan bahwa kehadiran dukungan sosial bisa membantu atau melindungi seseorang dari dampak negatif dari peristiwa yang menimbulkan stres. Hadirnya dukungan-dukungan sosial yang sesuai ini yang menumbuhkan rasa optimisme seseorang. Sebaliknya kehilangan atau ketiadaan social support dapat menimbulkan perasaaan kehilangan, perasaan tidak diakui keberadaanya.

Penelitian yang dilakukan oleh Arini (2009), Dari penelitian tersebut diperoleh hasil bahwa secara parsial intelegensi dan motivasi belajar berpengaruh secara signifikan terhadap prestasi akademik. Hal ini menunjukan seseorang peserta didik yang cerdas, apabila memiliki motivasi belajar yang rendah maka tidak akan mencapai prestasi akademik yang baik. Penelitian lain yang dilakukan oleh Neny (2012), dengan menunjukan hasil penelitian bahwa terdapat hubungan yang positif dan signifikan antara Self esteem dengan hasil prestasi akademik pada siswa jurusan pemasaran SMKN 48 Jakarta. Penelitian lain oleh Maslihah (2011) menunjukan adanya hubungan yang signifikan antara sosial support dengan prestasi akademik. dengan hasil penelitian tersebut menyatakan bahwa social support merupakan faktor yang mempengaruhi prestasi akademik.

Penelitian ini perlu dilakukan untuk menemukan bukti empiris terbaru atau bukti yang memperkuat hasil penelitian sebelumnya. Penelitian ini bertujuan untuk mengetahui pengaruh setiap variabel di bidang akademik. 


\section{Metode}

Penelitian ini menggunakan pendekatan kuantitatif dengan jenis penelitian explanatory research atau uji hubungan. Penelitian explanatory research bertujuan mengidentifikasi pengaruh variabel bebas terhadap variabel terikat dengan menggunakan angka dalam penafsiran data serta penyajian hasil penelitiannya.

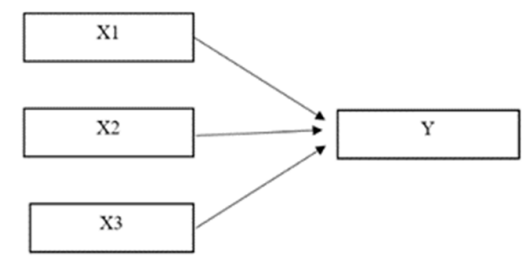

Gambar 1. Rancangan Penelitian

Keterangan :

$\longrightarrow$ Pengaruh variabel X1, X2, X3 secara parsial terhadap variabel $\mathrm{Y}$

X1: motivasi belajar

$\mathrm{X} 2$ : self esteem (harga diri)

$\mathrm{X}$ : social support (dukungan sosial orang tua)

Y: prestasi akademik

Populasi dalam penelitian ini adalah mahasiswa program studi S1 Pendidikan Akuntansi Universitas Negeri Malang angkatan 2015. Teknik pengambilan sampel yang digunakan dalam penelitian adalah Teknik purposive sampling, jumlah sampel yang digunakan sebesar 109 mahasiswa yang diperoleh dari rumus slovin dengan taraf kesalahan sebesar 5\%. Teknik pengumpulan data menggunakan kuesioner dan diukur menggunakan skala likert. Variabel penelitian akan dijabarkan menjadi indikator yang diperoleh dari teori dasar yang relevan dan kemudian diubah menjadi pernyataan. Teknik analisis data pada penelitian ini menggunakan Uji Asumsi Klasik dan Uji Regresi Linier Berganda. Uji Asumsi Klasik dalam penelitian ini meliputi Uji Normalitas, Uji Heteroskedastisitas, dan Uji Multikolinieritas. Uji Regresi Linier Berganda meliputi Uji t dan Analisis Koefisiensi Determinasi.

\section{Hasil dan Pembahasan}

\subsection{Uji Asumsi Klasik}

\subsubsection{Uji Normalitas}

Tabel 1. Hasil Uji Normalitas

\begin{tabular}{|c|c|c|}
\hline \multicolumn{3}{|c|}{ One-Sample Kolmogorof-Sminov Test } \\
\hline $\mathrm{N}$ & & 109 \\
\hline \multirow{2}{*}{ Normal Parameters ${ }^{a}$} & Mean & .0000000 \\
\hline & Standart Deviation & .22645261 \\
\hline \multirow[t]{3}{*}{ Most extreme Differences } & Absolute & .104 \\
\hline & Positive & .067 \\
\hline & Negative & -.104 \\
\hline Kolmogorof-Sminov Z & & 1.082 \\
\hline Asymp. Sig. (2-tailed) & & .193 \\
\hline
\end{tabular}


Pada tabel 1 diketahui bahwa nilai Asymp. Sig sebesar 0,193 lebih besar daripada nilai $\alpha$ sebesar 0,05 . Hal ini menandakan bahwa data dalam penelitian ini berdistribusi normal.

\subsubsection{Uji Heteroskedastisitas}

Tabel 2. Hasil Uji Heteroskedastisitas

\begin{tabular}{|c|l|c|l|c|c|c|c|c|}
\hline \multicolumn{2}{|c|}{} & B & $\begin{array}{l}\text { Std. } \\
\text { Error }\end{array}$ & Beta & T & Sig. & \multicolumn{2}{c|}{ Colineary Statistic } \\
\cline { 3 - 8 } & & 1.210 & .198 & & 6.095 & .000 & & \\
\hline 1 & Tolerance & VIF \\
\hline & $\begin{array}{l}\text { Motivasi } \\
\text { Belajar (X1) }\end{array}$ & .013 & .004 & .256 & 3.020 & .003 & .636 & 1.571 \\
\hline $\begin{array}{l}\text { Self Esteem } \\
\text { (X2) }\end{array}$ & .008 & .002 & .335 & 3.868 & .000 & .609 & 1.641 \\
\hline & $\begin{array}{l}\text { Social upport } \\
\text { orang tua (X3) }\end{array}$ & .016 & .005 & .270 & 3.056 & .003 & .585 & 1.710 \\
\hline
\end{tabular}

Pada Tabel 2 dapat diketahui bahwa nilai signifikansi motivasi belajar sebesar 0,003, self esteem (harga diri) sebesar 0,000, social support (dukungan sosial orang tua) sebesar 0,003. Dapat dilihat bahwa semua nilai Sig. > 0,05 yang berarti tidak terjadi heteroskedastisitas (homoskedastisitas).

\subsubsection{Uji Multikolinieritas}

Pada tabel 2 dapat dilihat nilai Tolerance untuk motivasi belajar sebesar 0,636, self esteem (harga diri) sebesar 0,609, social support (dukungan sosial keluarga) sebesar 0,585, atau berarti jika nilai Tolerance $>0,10$. Nilai VIF untuk motivasi belajar sebesar 1,571, self esteem (harga diri) sebesar 1,641, dukungan sosial (dukungan sosial orang tua ) sebesar 1,710, atau berarti nilai VIF < 10, sehingga dapat disimpulkan bahwa tidak terjadi multikolinieritas.

\subsection{Uji Regresi Linier Berganda}

\subsubsection{Uji t}

Tabel 3. Hasil Uji t

\begin{tabular}{|c|c|c|c|c|c|c|c|c|}
\hline \multicolumn{9}{|c|}{ Coefficients $^{a}$} \\
\hline & \multirow[t]{2}{*}{ Model } & \multicolumn{2}{|c|}{$\begin{array}{l}\text { Unstandardize } \\
\text { d Coefficients }\end{array}$} & \multirow{2}{*}{$\begin{array}{c}\begin{array}{c}\text { Standardize } \\
\text { d } \\
\text { Coefficients }\end{array} \\
\text { Beta }\end{array}$} & \multirow[t]{2}{*}{$\mathbf{t}$} & \multirow[t]{2}{*}{ Sig. } & \multicolumn{2}{|c|}{$\begin{array}{l}\text { Collinearity } \\
\text { Statistics }\end{array}$} \\
\hline & & B & $\begin{array}{c}\text { Std. } \\
\text { Error }\end{array}$ & & & & $\begin{array}{c}\text { Toleranc } \\
\text { e }\end{array}$ & VIF \\
\hline \multirow[t]{8}{*}{1} & (Constant & 1.21 & .198 & & 6.09 & .00 & & \\
\hline & ) & 0 & & & 5 & 0 & & \\
\hline & Motivasi & .013 & .004 & .256 & 3.02 & .00 & .636 & 1.57 \\
\hline & $\begin{array}{l}\text { belajar } \\
\text { (X1) }\end{array}$ & & & & 0 & 3 & & 1 \\
\hline & Self- & .008 & .002 & .335 & 3.86 & .00 & .609 & 1.64 \\
\hline & $\begin{array}{l}\text { esteem } \\
(\mathrm{X} 2)\end{array}$ & & & & 8 & 0 & & 1 \\
\hline & Social & .016 & .005 & .270 & 3.05 & .00 & .585 & 1.71 \\
\hline & support & & & & 6 & 3 & & 0 \\
\hline
\end{tabular}




\begin{tabular}{|c|c|c|c|c|c|c|c|}
\hline \multicolumn{8}{|c|}{ Coefficients $^{\mathbf{a}}$} \\
\hline \multirow[t]{2}{*}{ Model } & $\begin{array}{r}\text { Uns } \\
\text { d C }\end{array}$ & $\begin{array}{l}\text { ardize } \\
\text { cients }\end{array}$ & \multirow{2}{*}{$\begin{array}{c}\begin{array}{c}\text { Standardize } \\
\text { d } \\
\text { Coefficients }\end{array} \\
\text { Beta }\end{array}$} & \multirow[t]{2}{*}{$\mathbf{t}$} & \multirow[t]{2}{*}{ Sig. } & \multicolumn{2}{|c|}{$\begin{array}{l}\text { Collinearity } \\
\text { Statistics }\end{array}$} \\
\hline & B & $\begin{array}{l}\text { Std. } \\
\text { Error }\end{array}$ & & & & $\begin{array}{c}\text { Toleranc } \\
\mathbf{e}\end{array}$ & VIF \\
\hline $\begin{array}{l}\text { a. Dependent Variable: Prestasi } \\
\text { akademik (Y) }\end{array}$ & \multicolumn{6}{|c|}{$\begin{array}{l}\text { orang tua } \\
\text { (X3) }\end{array}$} & \\
\hline
\end{tabular}

Pada Tabel 3 dapat dilihat variabel motivasi belajar (X1) menunjukkan nilai t hitung sebesar 3,020 dan nilai t tabel sebear 1,982 yang berarti nilai t hitung > t tabel. Sedangkan nilai signifikansi sebesar 0,003<0,05, hal ini menunjukkan bahwa H0 ditolak dan Ha diterima. Maka dapat disimpulkan bahwa variabel motivasi belajar (X1) memiliki pengaruh yang signifikan terhadap variabel prestasi akademik (Y).

Variabel self esteem (harga diri) (X2) menunjukkan nilai t hitung sebesar 3,868 dan nilai t tabel sebesar 1,982 yang berarti nilai t hitung $>$ t tabel. Sedangkan nilai signifikansi sebesar $0,000<0,05$, hal ini menunjukkan bahwa H0 ditolak dan Ha diterima. Maka dapat disimpulkan bahwa variabel self esteem (harga diri) (X2) memiliki pengaruh yang signifikan terhadap variabel prestasi akademik (Y).

Variabel social support (dukungan sosial orang tua) (X3) menunjukkan nilai t hitung sebesar 3,056 dan nilai t tabel sebear 1,982 yang berarti nilai t hitung > t tabel. Sedangkan nilai signifikansi sebesar 0,003 < 0,05, hal ini menunjukkan bahwa H0 ditolak dan Ha diterima. Maka dapat disimpulkan bahwa variabel social support (dukungan sosial orang tua) (X3) memiliki pengaruh yang signifikan terhadap variabel prestasi akademik (Y).

\subsection{Analisis Koefisien Determinasi}

Tabel 4. Hasil Analisis Koefisien Determinasi

\begin{tabular}{|c|c|c|c|c|c|}
\hline \multicolumn{6}{|c|}{ Model Summary b } \\
\hline Model & $\mathrm{R}$ & $\begin{array}{l}\mathrm{R} \\
\text { Square }\end{array}$ & $\begin{array}{l}\text { Adjusted R } \\
\text { Square }\end{array}$ & $\begin{array}{l}\text { Std. Error of the } \\
\text { Estimate }\end{array}$ & $\begin{array}{l}\text { Durbin- } \\
\text { Watson }\end{array}$ \\
\hline 1 & $.721^{a}$ & .520 & .506 & .22966 & 1.853 \\
\hline
\end{tabular}

Pada Tabel 4 diketahui bahwa nilai R Square sebesar 0,520 x 100\% = 52\%. Hal ini menunjukkan bahwa 52\% prestasi akademik (Y) dipengaruhi oleh motivasi belajar (tekanan akademik) (X1), self estem (harga diri) (X2), social support (dukungan sosial orang tua) (X3).

\subsection{Pengaruh Motivasi belajar terhadap Prestasi akademik}

Berdasarkan hasil analisis telah dilakukan peneliti dapat dilihat bahwa variabel motivasi belajar memiliki pengaruh yang signifikan terhadap prestasi akademik. Hal ini berarti semakin tinggi motivasi belajar mahasiswa, maka semakin tinggi prestasi akademik yang didapatkan. Pada penelitian ini, motivasi belajar yang paling banyak mempengaruhi mahasiswa adalah kegiatan belajar yang menarik. Sedangkan motivasi belajar yang memiliki pengaruh paling kecil adalah adanya pemberian hadiah dan hukuman. 
Hasil penelitian ini mendukung penelitian terdahulu yang dilakukan oleh Silvia (2016) dan menjelaskan bahwa mahasiswa yang memiliki motivasi belajar yang kuat akan mendapatkan prestasi akademik yang tinggi. Penelitian lain juga dilakukan oleh Aliyazzahroh (2016) menjelaskan bahwa terdapat pengaruh antara motivasi belajar mahasiswa dengan prestasi belajar mahasiswa. Jika tingkat motivasi mahasiswa sebagai subjek otomatis objeknya dalam hal ini adalah prestasi akademik juga akan meningkat. Begitupun sebaliknya jika subjek rendah maka objek akan rendah juga.

\subsection{Pengaruh Self estem (Harga diri) terhadap Prestasi akademik}

Berdasarkan hasil analisis telah dilakukan peneliti dapat dilihat bahwa variabel self estem (harga diri) memiliki pengaruh yang signifikan terhadap prestasi akademik. Hal ini berarti semakin tinggi self esteem seseorang maka akan tinggi juga prestasi akademiknya. Pada penelitian ini, self estem (harga diri) yang paling berpengaruh dalam penelitian ini disebabkan oleh merasa mempunyai keistimewaan yang tidak dimiliki oleh orang lain. sedangkan self estem (harga diri) yang memiliki pengaruh paling kecil adalah perasaan populer dan dikenal oleh banyak orang.

Hasil penelitian ini mendukung penelitian terdahulu yang dilakukan oleh Neny (2012) dan menjelaskan bahwa self esteem dalam diri seseorang harus dibangun dikarenakan dengan tingkat self esteem yang baik seseorang akan lebih bersungguh-sungguh dalam menumbuhkan keyakinan dan kemampuan dirinya untuk dapat mencapai prestasi akademik. Peningkatan self esteem dalam diri seseorang ditandai dengan mengerjakan tugas, belajar dengan giat, memperbanyak latihan soal yang akan membuat seseorang dapat mencapai prestasi akademik yang baik. Penelitian lain juga dilakukan oleh Neny (2012) yang menunjukkan adanya hubungan yang positif antara self esteem dengan prestasi.

\subsection{Pengaruh Social support (Dukungan sosial orang tua) terhadap Prestasi akademik}

Berdasarkan hasil analisis telah dilakukan peneliti dapat dilihat bahwa variabel social support (dukungan sosial orang tua) memiliki pengaruh yang signifikan terhadap prestasi akademik. Hal ini berarti semakin tinggi tingkat social support yang dimiliki mahasiswa, maka semakin tinggi prestasi akademik yang didapatkan. Pada penelitian ini, social support (dukungan sosial orang tua) yang paling berpengaruh dalam penelitian ini disebabkan oleh mendapatkan nasehat atau masukan. Sedangkan social support (dukungan sosial orang tua) yang memiliki pengaruh paling kecil adalah ikut terlibat dalam permasalahan.

Hasil penelitian ini mendukung penelitian terdahulu yang dilakukan oleh Rensi dkk (2010) menyatakan bahwa social support yang diberikan memiliki pengaruh terhadap prestasi akademik seseorang. Penelitian lain juga dilakukan oleh Elita (2014) menyatakan social support adalah salah satu faktor yang mempengaruhi orang untuk berprestasi, hal ini membuktikan bahwa social support berhubungan langsung dengan hasil prestasi seseorang. Semakin tinggi social support yang diberikan orang tua dapat lebih mendorong mahasiswa untuk lebih semangat lagi dalam melakukan studi agar bisa meraih prestasi akademik yang baik. 


\section{Simpulan}

Berdasarkan penjabaran analisis yang sudah dipaparkan, maka dapat ditarik kesimpulan yaitu terdapat pengaruh positif antara motivasi belajar terhadap prestasi akademik mahasiswa. Hal ini berarti semakin tinggi motivasi belajar mahasiswa, maka semakin tinggi prestasi akademik yang didapatkan. Motivasi belajar yang paling banyak mempengaruhi mahasiswa adalah kegiatan belajar yang menarik. Terdapat pengaruh positif antara self estem (harga diri) terhadap prestasi akademik mahasiswa. Hal ini berarti semakin tinggi self esteem seseorang maka akan tinggi juga prestasi akademiknya. Self estem (harga diri) yang paling berpengaruh dalam penelitian ini disebabkan oleh merasa mempunyai keistimewaan yang tidak dimiliki oleh orang lain. Terdapat pengaruh positif antara social support (dukungan sosial orang tua) terhadap prestasi akademik mahasiswa. Hal ini berarti semakin tinggi tingkat social support yang dimiliki mahasiswa, maka semakin tinggi prestasi akademik yang didapatkan.. Social support (dukungan sosial orang tua) yang paling berpengaruh dalam penelitian ini disebabkan oleh mendapatkan nasehat atau masukan.

\section{Daftar Rujukan}

Oemar, H. (2008). Kurikulum dan Pembelajaran, Bumi Aksara

Djamarah, S. B. (2000). Guru dan anak didik dalam interaksi edukatif. Rineka cipta.

Bustanova, B. (2008). Self-esteem dan Narcissistic Personality. Tersedia pada: http://bustanova. wordpress.com. [diunduh 11 Maret 2019].

Greenberg, J. (2008). Understanding the vital human quest for self-esteem. Perspectives on Psychological Science, 3, 48-55.

Sarafino, E. P., \& Smith, T. (2011). Health psychology biopsychosocial interaction. United State of America: John Wlley \& Sons.

Arini, N. K. S., \& Fakhrurrozi, M. (2008). Pengaruh Tingkat Intelegensi dan Motivasi Belajar terhadap Prestasi Akademik Siswa Kelas II SMA Negeri 99 Jakarta. Unpublished Laporan Penelitian. Jakarta: Universitas Gunadarma.

Irawati, N., \& Hajat, N. (2012). Hubungan antara harga diri (self-esteem) dengan prestasi belajar pada siswa SMKN 48 di Jakarta Timur. Econosains Jurnal Online Ekonomi dan Pendidikan, 10(2), 193-210.

Maslihah, S. (2011). Studi tentang hubungan dukungan sosial, penyesuaian sosial di lingkungan sekolah dan prestasi akademik siswa SMPIT Assyfa Boarding School Subang Jawa Barat. Jurnal Psikologi, 10(2), 103114.

Sylvia, R. (2016). Hubungan self-esteem dan motivasi belajar terhadap pendidikan kewarganegaraan. Jurnal Pendidikan Dasar, 7(2), 311-328.

Ailiyazzahroh, L. L. (2016). Pengaruh motivasi belajar terhadap prestasi akademik musyrif-musyrifah Pusat Ma'had Al-Jami'ah (Doctoral dissertation, Universitas Islam Negeri Maulana Malik Ibrahim).

Rensi, R., \& Sugiarti, L. R. (2011). Dukungan sosial, konsep diri, dan prestasi belajar siswa SMP Kristen YSKI Semarang. Jurnal Psikologi, 3(2).

Putri, E. P. (2014). Hubungan dukungan sosial orang tua, pelatih dan teman dengan motivasi berprestasi akademik dan motivasi berprestasi olahraga (basket) pada mahasiswa atlet basket Universitas Surabaya. CALYPTRA, 3(1), 1-11. 